\title{
Article \\ Can Ethylene Inhibitors Enhance the Success of Olive Somatic Embryogenesis?
}

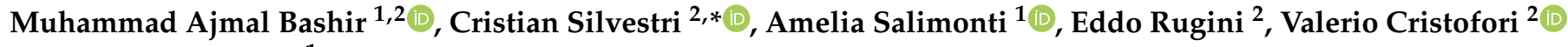 \\ and Samanta Zelasco ${ }^{1}$ \\ 1 Council for Agricultural Research and Economics (CREA), Research Centre for Olive, Citrus and Tree Fruit, \\ C/da Li Rocchi Vermicelli, 87036 Rende, Italy; muhammadajmal@unitus.it (M.A.B.); \\ amelia.salimonti@crea.gov.it (A.S.); samanta.zelasco@crea.gov.it (S.Z.) \\ 2 Department of Agriculture and Forest Sciences, University of Tuscia, Via San Camillo De Lellis s.n.c., \\ 01100 Viterbo, Italy; rugini@unitus.it (E.R.); valerio75@unitus.it (V.C.) \\ * Correspondence: silvestri.c@unitus.it
}

check for updates

Citation: Bashir, M.A.; Silvestri, C.; Salimonti, A.; Rugini, E.; Cristofori,

V.; Zelasco, S. Can Ethylene Inhibitors Enhance the Success of Olive Somatic Embryogenesis? Plants 2022, 11, 168. https://doi.org/10.3390/

plants11020168

Academic Editor: Shri Mohan Jain

Received: 7 December 2021

Accepted: 6 January 2022

Published: 9 January 2022

Publisher's Note: MDPI stays neutral with regard to jurisdictional claims in published maps and institutional affiliations.

Copyright: (c) 2022 by the authors. Licensee MDPI, Basel, Switzerland. This article is an open access article distributed under the terms and conditions of the Creative Commons Attribution (CC BY) license (https:// creativecommons.org/licenses/by/ $4.0 /)$.

\begin{abstract}
An efficient in vitro morphogenesis, specifically through somatic embryogenesis, is considered to be a crucial step for the application of modern biotechnological tools for genetic improvement in olive (Olea europaea L.). The effects of different ethylene inhibitors, i.e., cobalt chloride $\left(\mathrm{CoCl}_{2}\right)$, salicylic acid (SA), and silver nitrate $\left(\mathrm{AgNO}_{3}\right)$, were reported in the cyclic somatic embryogenesis of olive. Embryogenic callus derived from the olive immature zygotic embryos of the cultivar Leccino, was transferred to the expression ECO medium, supplemented with the ethylene inhibitors at 20 and $40 \mu \mathrm{M}$ concentrations. Among these, the maximum number of somatic embryos (18.6) was obtained in media containing silver nitrate $(40 \mu \mathrm{M})$, followed by cobalt chloride (12.2 somatic embryos @ $40 \mu \mathrm{M})$ and salicylic acid $(40 \mu \mathrm{M})$, which produced 8.5 somatic embryos. These compounds interfered on callus traits: white friable embryogenic calli were formed in a medium supplemented with $40 \mu \mathrm{M}$ cobalt chloride and salicylic acid; in addition, a yellow-compact embryogenic callus appeared at $20 \mu \mathrm{M}$ of all the tested ethylene inhibitors. The resulting stimulatory action of silver nitrate among all the tested ethylene inhibitors on somatic embryogenesis, clearly demonstrates that our approach can efficiently contribute to the improvement of the current SE protocols for olive.
\end{abstract}

Keywords: cobalt chloride; de novo organogenesis; Olea europaea L.; salicylic acid; silver nitrate

\section{Introduction}

Olive (Olea europaea L.) plants belong to the family Oleaceae, and are one of the most popular species of the genus Olea, which is commonly grown in the Mediterranean region and used for food purposes [1]. Furthermore, more than 750 million olive trees are cultivated worldwide. Among the more than one thousand known varieties, of which there are about 600 in Italy, very few are suitable for modern cultivation systems, and the development of novel cultivars is often hampered by the most commonly used breeding techniques that are time-consuming [2]. Although olive, in general, is difficult to be manipulated, in vitro, many cultivars have been established in vitro and micro propagated [3]. Moreover, in vitro culture has always been an excellent tool to support the various laboratory techniques used for genetic, microbiological, physiological, and biochemical studies [4], including biotechnological approaches.

In vitro morphogenesis through somatic embryogenesis is considered as the fundamental step for the application of different biotechnological tools for unconventional breeding in many fruit species, including olives [1]. Previously, somatic embryogenesis has been successfully achieved from zygotic embryos [5,6], radicle and cotyledon segments derived from mature embryos [7-10]. Furthermore, somatic embryogenesis has also been achieved from mature tissues [1,11-15]. The induction and regeneration of somatic embryos are highly sensitive to culture conditions, such as the medium composition, 
physical environment of the culture, and the genotype and explant source, especially in olives $[1,2,15,16]$.

There are various factors that influence the somatic embryogenesis response in different plant species. Among them, ethylene is known to inhibit in vitro morphogenetic responses in a genotype-specific manner [17]. Ethylene is recognized as a ubiquitous plant hormone, which has a wide variety of effects on the growth and development of intact plants [18]. It is one of the compounds produced during in vitro culture vessels up to a physiological threshold [19]. The involvement of ethylene in plant tissue growth and differentiation has been widely investigated [20]. Previous studies have demonstrated that ethylene could influence in vitro morphogenetic response in plants [21-23]. Therefore, regulation of ethylene perception or ethylene biosynthesis seems to be a promising approach for increasing the efficiency of tissue culture protocols in plant systems. Among these ethylene inhibitors, silver nitrate has been known to inhibit ethylene action [24], and cobaltous ions inhibit ethylene biosynthesis [25], whereas salicylic acid has also been proven to be a potent inhibitor of ethylene biosynthesis [26].

Plant regeneration systems, such as organogenesis and somatic embryogenesis (SE), are eminent micropropagation processes that are based on plant cell totipotency. In organogenesis, plant organs, such as shoots, roots, and even flowers, can be formed from cultured explants. However, for micropropagation purposes, the most interesting factor is de novo shoot meristem formation followed by shoot growth and rooting [27], whereas SE is a more complex developmental pathway, by which the bipolar structures identical to zygotic embryos are developed from the somatic cells through a complex dedifferentiation process, followed by totipotency acquisition and the formation of somatic embryos [28,29]. Since the production of ethylene is directly involved in explant browning and plant morphogenesis under in vivo and in vitro conditions, the inclusion of the compounds that inhibit ethylene biosynthesis are a good alternative to modulate morphogenesis in plant cell and tissue culture. Although different ethylene inhibitors are reported to promote in vitro shoot organogenesis in various economically important plant species [30], the mechanism of their stimulatory effect in olive has not yet been exercised. In the present study, we establish a more efficient and reliable protocol for the induction of somatic embryogenesis in olives, by studying the involvement of different ethylene inhibitors in the culture media.

\section{Results and Discussion}

The control of biotic contamination is one of the major concerns in the in vitro establishment of olive material. However, the establishment of callus culture starting from the immature zygotic embryos was very easy due to the absence of endogenous contaminants inside the seeds, and because the olive stones, more susceptible to contaminants, can be strongly surface disinfected (Figure 1a), without compromising the viability of the well protected embryos (Table 1) (Figure 1b,c).

Table 1. The contamination rates of the different explant sources (immature embryos of cv. Leccino and uni-nodal explants of the cultivars CS-3T and F7P3) and the bud development from the aseptic nodal explants of both cultivars. Data have been shown as the mean \pm standard deviation. The mean denoted by different letters are significantly different (Duncan's test, $p<0.05$ ).

\begin{tabular}{ccc}
\hline Explant Source & Contamination Rate (\%) & Explants Forming Shoots (\%) \\
\hline Zygotic Embryo of Leccino & $2.1 \pm 0.7$ & - \\
\hline Nodes of CS-3T & $56.4 \pm 3.8 \mathrm{a}$ & $78.4 \pm 8.8$ \\
\hline Nodes of F7P3 & $33.2 \pm 2.9 \mathrm{~b}$ & $68.9 \pm 10.2$ \\
\hline
\end{tabular}

For the in vitro establishment of the cultivars F7P3 and CS-3T, the disinfection procedure used was very efficient, with more than $40 \%$ of aseptic explants, with greater success in the "F7P3", as confirmed by the statistical analysis (Table 1). The differences observed among the cultivars are in line with the literature, and confirm that olive micropropagation, 
including the phase of in vitro establishment, are genotype dependent [2]. Subsequently, the buds of the aseptic nodal explants were able to convert into normal shoots in both cultivars, CS-3T and F7P3 (78.4 and 69.8\%, respectively) (Figure 1e,f). These differences observed between the cultivars are in line with the literature, and confirm that olive micropropagation, including the phase of in vitro establishment, are genotype dependent [2]; only a few shoots were hyperhydrated (Figure 1d), which rapidly became necrotic.

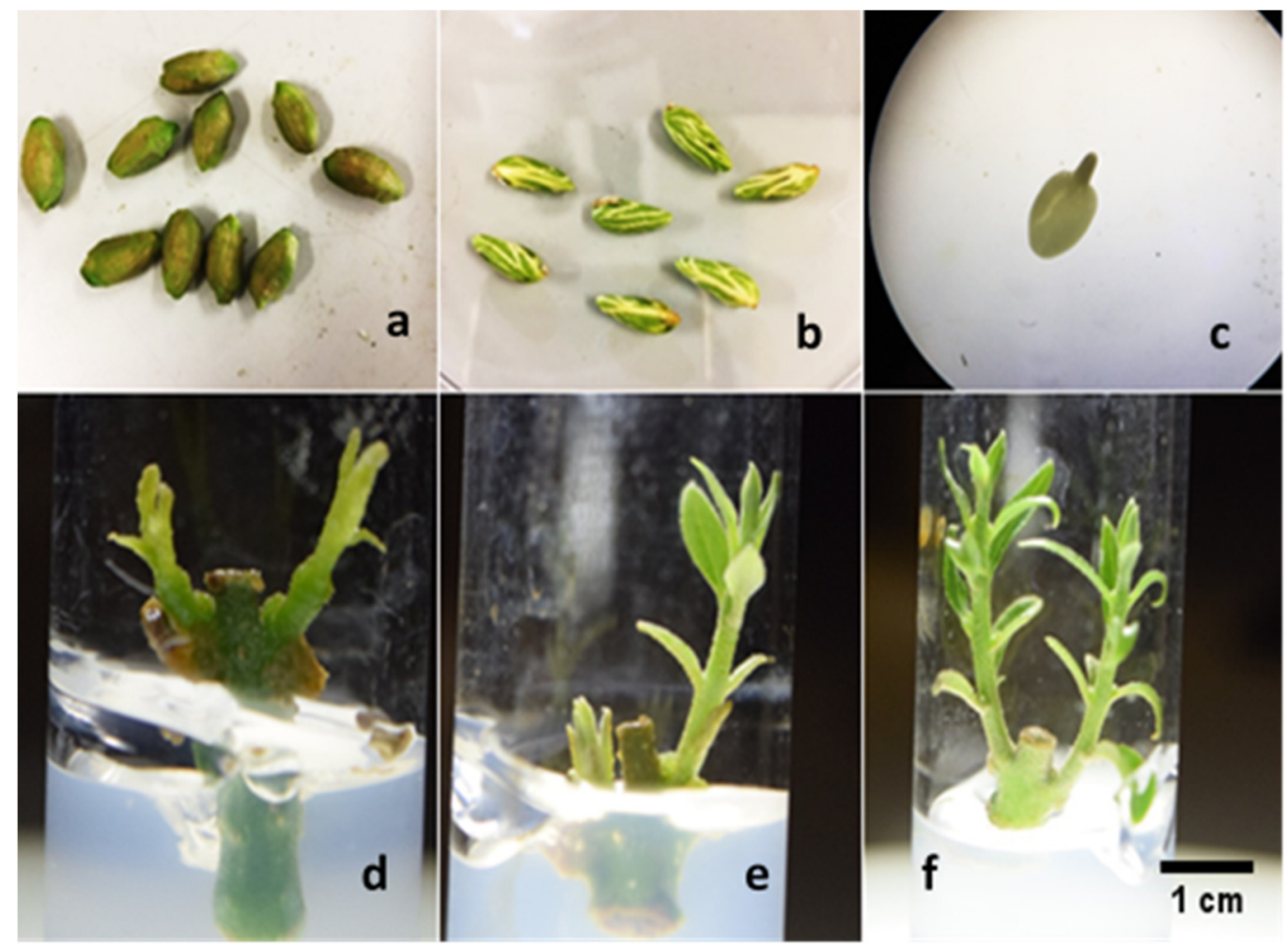

Figure 1. Lignified endocarp containing immature seeds (a), seeds released from the sclerified endocarp (b), naked embryos after endocarp, and seed coat and endosperm removed (c). Nodal explant producing hyperhydrated shoots, usually unable to convert into normal ones (d), normal shoots originated from the buds of the nodal explants of the cultivars F7P3 (e), and CS-3T (f). (Scale bar $=1 \mathrm{~cm})$.

In the induction medium, the callus formation from both the immature zygotic embryos and from the shoot apex (leaf primordia) of the cultivars F7P3 and CS-3T, has been observed after 3-4 weeks of culture. The putative embryogenic calli derived from the immature zygotic embryos showed a higher callus proliferation rate than those from the cultivars F7P3 and CS-3T (Table 2); in particular, the calli derived from the embryos were white and friable (Figure 2a), while most of the calli derived from cultivars F7P3 and CS-3T appeared heterogeneous, yellowish and compact (Table 2 and Figure 2b). Surprisingly, by the end of the 4 th week of culture on the induction medium, some embryo-like structures (Figure 2c) or embryos (Figure 2d) appeared on the three genotypes. 
Table 2. The callus formation of the different explant sources of the immature embryos of cv. Leccino, and the leaflets of growing shoots from the varieties CS-3T and F7P3, after 4 weeks on the induction medium. Data are reported as the mean \pm standard deviation. The mean denoted by different letters are significantly different (Duncan's test, $p<0.05$ ). The amount of callus formation has been estimated by an arbitrary scale (0 no callus, $1:<40 \%, 2: 40-80 \%$, and 3: $80-100 \%$ ) on visual criteria, as recommended by [15].

\begin{tabular}{cccc}
\hline Explant Source & $\begin{array}{c}\text { Explant Forming } \\
\text { Callus (\%) }\end{array}$ & Amount of Callus & Callus Traits \\
\hline $\begin{array}{c}\text { Zygotic Embryo } \\
\text { Leccino }\end{array}$ & 100 & $2.8 \pm 0.3 \mathrm{a}$ & White and friable \\
\hline Variety CS-3T & $90 \pm 5$ & $2.2 \pm 0.3 \mathrm{~b}$ & $\begin{array}{c}\text { White/yellowish } \\
\text { compact }\end{array}$ \\
\hline Variety F7P3 & $95 \pm 3$ & $1.9 \pm 0.2 \mathrm{~b}$ & $\begin{array}{c}\text { Yellowish and } \\
\text { compact/friable }\end{array}$ \\
\hline
\end{tabular}

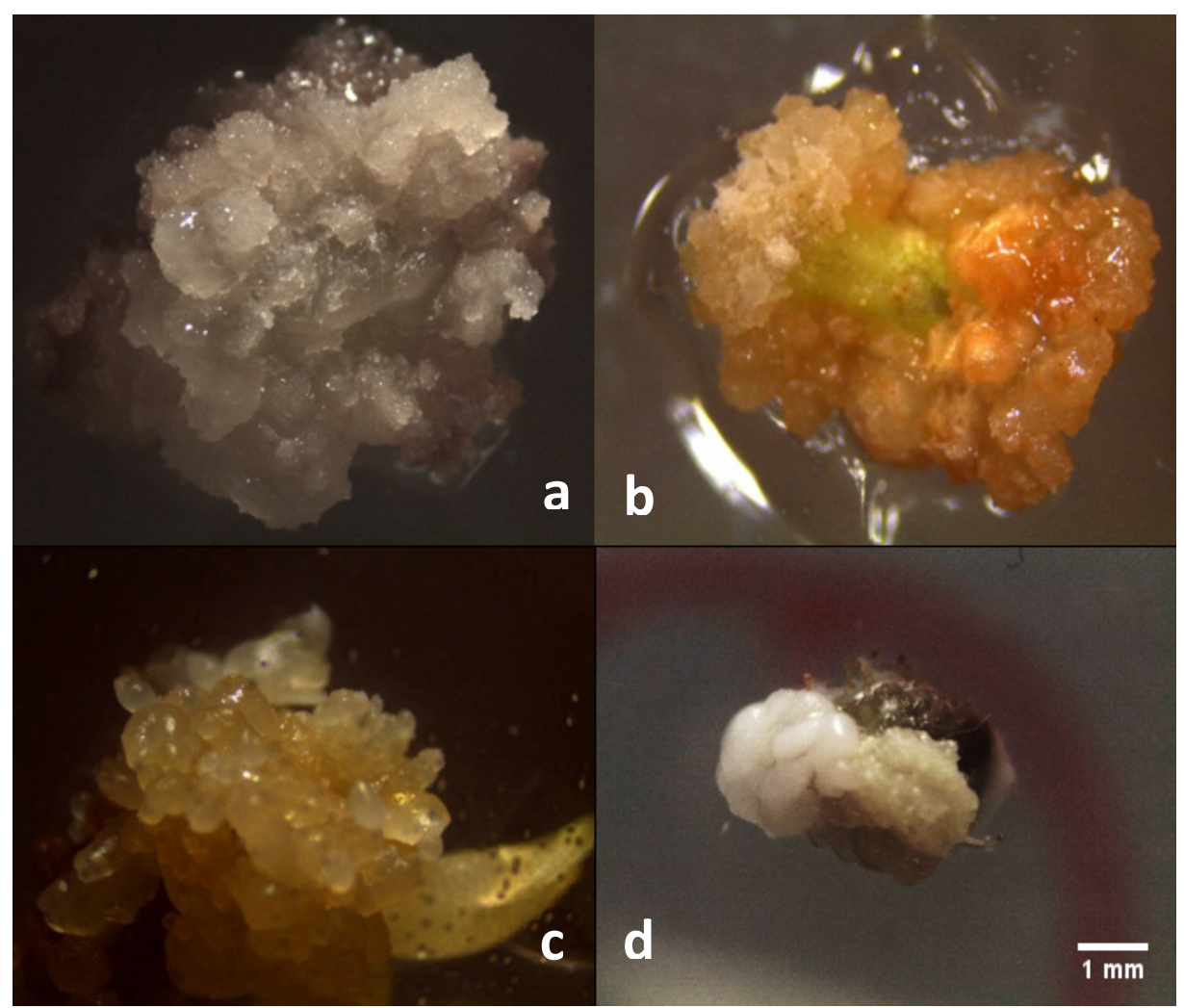

Figure 2. White callus derived from the zygotic embryos of open-pollinated cv. Leccino (a) and the yellowish callus derived from the shoot apex of the cultivar CS-3T (b). Embryo-like structures in CS-3T (c) and the aggregation of well-formed embryos on the callus surface of cultivar F7P3 (d). (Scale bar $=1 \mathrm{~mm}$ ).

On the expression medium, callus growth was observed in all the media containing different combinations of ethylene inhibitors and in the control medium (lacking ethylene inhibitors). In medium supplemented with $40 \mu \mathrm{M}$ of $\mathrm{AgNO}_{3}$, after the third week of culture, the callus showed a higher percentage of embryogenic callus formation $(68.71 \%)$, followed by $40 \mu \mathrm{M}$ of SA treatment with $60.4 \%$ of embryogenic callus. As expected, the lowest percentage of embryogenic callus (15.3\%) was observed in medium without any ethylene inhibitors (control) and, furthermore, failed to turn into somatic embryos in most cases, allowing to the recovery of only a few normal embryos (Figure 3d). Statistical analysis showed that the rates of callogenesis were not significantly different among the media 
containing the ethylene inhibitors $\mathrm{AgNO}_{3}$ and SA at concentrations of $20 \mu \mathrm{M}$, compared to $\mathrm{CoCl}_{2}$, which produced a statistically lower percentage at $20 \mu \mathrm{M}$. Silver nitrate $\left(\mathrm{AgNO}_{3}\right)$ tested at all concentrations $(20$ and $40 \mu \mathrm{M})$ induced markedly higher numbers $(9.2$ and 18.6, respectively) of the somatic embryos per explant. However, the somatic embryos obtained from $20 \mu \mathrm{M}$ of $\mathrm{AgNO}_{3}$ turned a deep brown color and could not convert into complete somatic embryos. Among all these ethylene inhibitors, the maximum number of somatic embryos was produced in media containing $40 \mu \mathrm{M}\left(\mathrm{AgNO}_{3}\right)$ (Figure $\left.3 \mathrm{~d}\right)$, followed by $40 \mu \mathrm{M}\left(\mathrm{CoCl}_{2}\right), 20 \mu \mathrm{M}\left(\mathrm{AgNO}_{3}\right)$, and then SA $(40 \mu \mathrm{M})$ (Figure 3a,e,f). The embryogenic calli growing on $40 \mu \mathrm{M}$ of cobalt chloride $\left(\mathrm{CoCl}_{2}\right)$ and salicylic acid produced compact somatic embryo-like structures, but they were unable to develop into a complete cotyledonary structure. Concerning the appearance of callus, friable calli were produced on medium supplemented with $20 \mu \mathrm{M}$ of cobalt chloride (Figure 3c), and off-white-to-yellow colored calli were observed at $20 \mu \mathrm{M}$ of SA. The globular embryos obtained from the different treatments have been able to convert into plants without any difference attributable to the type of ethylene inhibitor used.

The results presented in this experiment confirm that the use of ethylene inhibitors in culture media can enhance the ability of olive tissue cultures to produce a higher number of somatic embryos per explant. The highest number of somatic embryos was achieved on media supplemented with $40 \mu \mathrm{M}$ of $\mathrm{AgNO}_{3}$. This result agrees with the previously reported findings demonstrating the stimulative role of $\mathrm{AgNO}_{3}$ on shoot organogenesis in many plant species, such as banana [30], Coffea [31], strawberry [32], sweet potato [33], sesame [34], tomato [35], and turmeric [36]. For $\mathrm{CoCl}_{2}$ and SA treatments, a lower number of somatic embryos were achieved, compared to the $\mathrm{AgNO}_{3}$ treatment. It is well known that $\mathrm{AgNO}_{3}$ is a potent inhibitor of ethylene action [37], whereas $\mathrm{CoCl}_{2}$ and $\mathrm{SA}$ are known to inhibit the enzymes aminocyclopropane-1-carboxylic acid (ACC) synthase and ACC oxidase involved in ethylene biosynthesis [38,39].

There are several reports in literature that clearly show that ethylene influences callus growth, shoot regeneration, and somatic embryogenesis in other plant species [40,41], but not in olive. However, in the present study, the treatment with silver nitrate significantly increased the SE production. Therefore, it can be suggested that silver nitrate is an ethylene action inhibitor, which affects somatic embryogenesis by increasing or decreasing the in vitro response of explants, depending on the species [42,43].

The precise mechanism of ethylene inhibitor action on plants is still uncertain. However, few existing evidences suggest their interference in the ethylene perception mechanism. Recently, $\mathrm{AgNO}_{3}$ has been employed in plant tissue culture studies for inhibiting ethylene action due to its water solubility and lack of phytotoxicity at certain concentrations [44]. To summarize, the findings of this study demonstrate that ethylene inhibitors, particularly $\mathrm{AgNO}_{3}$ and to a lesser extent $\mathrm{CoCl}_{2}$ and $\mathrm{SA}$, enhanced the somatic embryogenic ability in olive explants (Table 3 ). Therefore, the effect of silver nitrate on somatic embryogenesis can be carefully evaluated for each species. In our study, the resulting stimulatory action of silver nitrate among other ethylene inhibitors tested on somatic embryogenesis, clearly demonstrated its effective contribution to improve the somatic embryogenesis protocols for olive. 


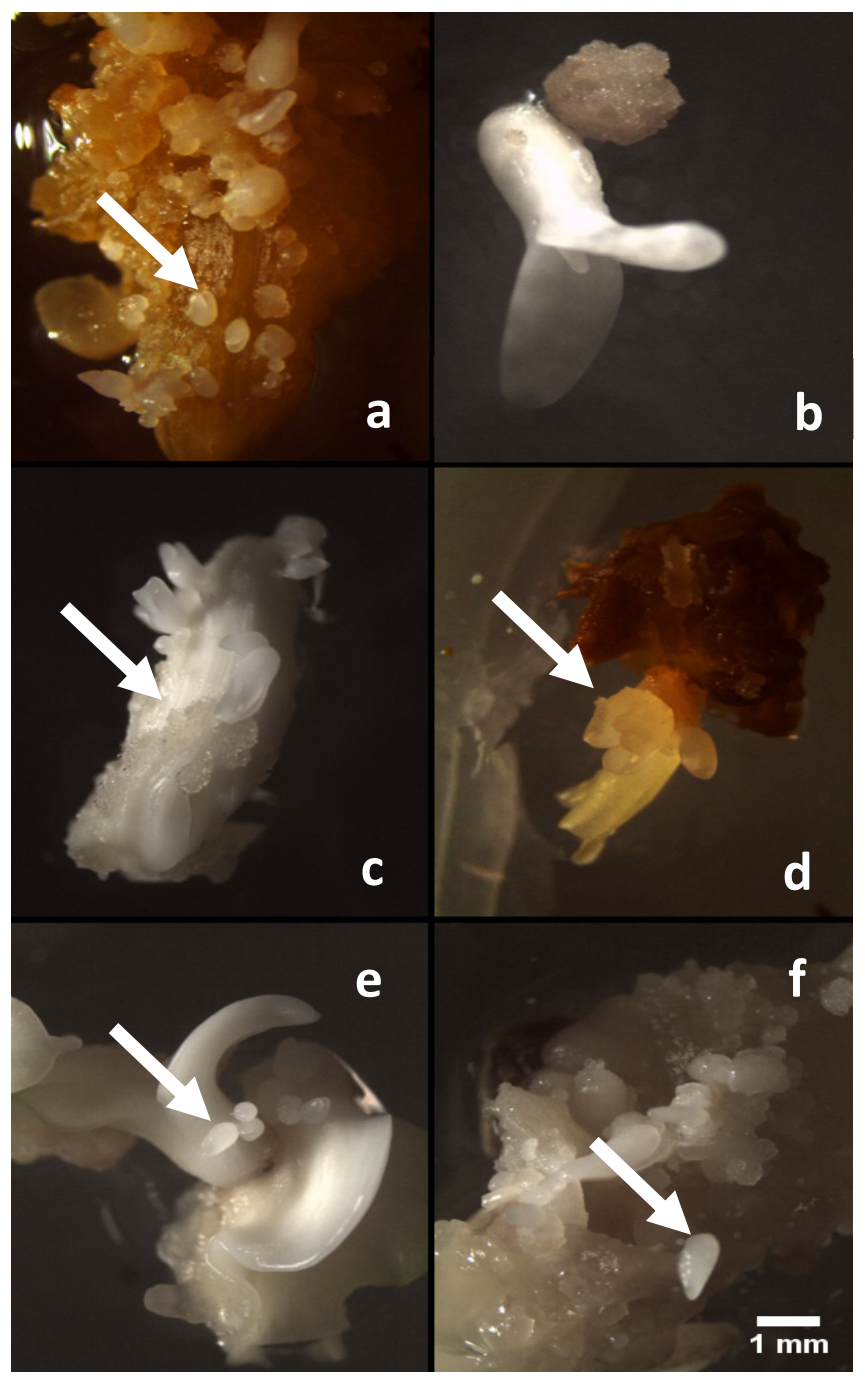

Figure 3. Effect of the ethylene inhibitors on somatic embryogenesis from callus derived from zygotic embryos at different concentrations of $\mathrm{AgNO}_{3} 20 \mu \mathrm{M}$ (a), salicylic acid $20 \mu \mathrm{M}$ (b), $\mathrm{CoCl}_{2} 20 \mu \mathrm{M}$ (c), $\mathrm{AgNO}_{3} 40 \mu \mathrm{M}(\mathbf{d})$, salicylic acid $40 \mu \mathrm{M}$ (e), and CoCl2 $40 \mu \mathrm{M}$ (f), after four weeks in culture. (Scale bar $=1 \mathrm{~mm})$. White arrows show the well-formed embryos.

Table 3. The effect of ethylene inhibitors on the percentage of embryogenic callus formation and the number of somatic embryos recovered. The data are reported as the mean \pm standard deviation. The mean denoted by different letters are significantly different (Duncan's test, $p<0.05$ ).

\begin{tabular}{ccc}
\hline Ethylene Inhibitors & Embryogenic Callus (\%) & Number of Somatic Embryos per Callus \\
\hline Control & $15.3 \pm 2.1 \mathrm{~cd}$ & $3.8 \pm 0.3 \mathrm{~d}$ \\
\hline $\mathrm{AgNO}_{3} 20 \mu \mathrm{M}$ & $23.8 \pm 4.2 \mathrm{c}$ & $9.2 \pm 0.3 \mathrm{bc}$ \\
\hline $\mathrm{AgNO}_{3} 40 \mu \mathrm{M}$ & $68.7 \pm 8.1 \mathrm{a}$ & $18.6 \pm 0.2 \mathrm{a}$ \\
\hline $\mathrm{SA} 20 \mu \mathrm{M}$ & $26.0 \pm 4.5 \mathrm{bc}$ & $6.0 \pm 0.3 \mathrm{~cd}$ \\
\hline $\mathrm{SA} 40 \mu \mathrm{M}$ & $60.4 \pm 4.1 \mathrm{~b}$ & $8.5 \pm 0.2 \mathrm{bc}$ \\
\hline $\mathrm{CoCl}_{2} 20 \mu \mathrm{M}$ & $12.2 \pm 1.5 \mathrm{~d}$ & $7.3 \pm 0.3 \mathrm{c}$ \\
\hline $\mathrm{CoCl}_{2} 40 \mu \mathrm{M}$ & $28.1 \pm 4.0 \mathrm{bc}$ & $12.2 \pm 0.2 \mathrm{~b}$
\end{tabular}

y SA (salicylic acid). 


\section{Materials and Methods}

\subsection{Plant Material}

Immature zygotic embryos were taken from adult and healthy, and open-pollinated olive trees in cv. Leccino, sixty days after full bloom. The pulp of the immature fruits has been eliminated (Figure 1a) and the endocarp (stone) was washed in running tap water, then submerged in a solution of commercial bleach $20 \% v / v$ and a few drops of Tween-80 for $20 \mathrm{~min}$. Finally, the olive stones were washed again with sterilized autoclaved water and dried in a laminar flow hood under aseptic conditions. The disinfected stones were opened by using a nutcracker, and the seeds were removed (Figure 1b) and used immediately or stored in Petri dishes in a refrigerator $\left(10^{\circ} \mathrm{C}\right)$ for a week to extract the embryos using a knife. Immature zygotic embryos (Figure 1c) were cultured in half-strength MS medium (including vitamins) supplemented with $0.44 \mathrm{mg} \mathrm{L}^{-1}$ BAP. Callus produced after 4 weeks was then used as the plant material for our study.

Regarding the adult material, two cultivars have been used. The clone F7P3 an CS-3T have been established in vitro from potted plants grown in a greenhouse. Briefly, the distal portion of the twigs of the potted plants were cut and the plants were sprayed with fungicides, 7 days and $24 \mathrm{~h}$ prior to harvesting the explants to be used for the in vitro establishment. The nodal explants were rinsed in running tap water, then immersed for $30 \mathrm{~s}$ in ethanol 70\% $(v / v)$, and then soaked for 15-30 min in an aqueous solution of ascorbic acid $250 \mathrm{mg} \mathrm{L}^{-1}$ and $\mathrm{PPM}^{\circledR}$ (Plant Preservative Mixture) $0.1 \%(v / v)$. Decontamination was performed with a solution of commercial bleach $20 \%$ and a few drops of Tween- 80 for $20 \mathrm{~min}$. The explants were rinsed three times in sterile deionized water and placed in $15 \mathrm{~mL}$ tubes containing medium consisting of OM medium, including vitamins [33] supplemented with mannitol 3.6\%, L-Glutamine $2.2 \mathrm{~g} \mathrm{~L}^{-1}$, zeatin $\left(4.56 \mu \mathrm{M}\right.$ ), and $\mathrm{GA}_{3} 1.44 \mu \mathrm{M}$ (added filter sterilized after autoclaving). The aseptic neo-formed shoots have been dissected and transferred to a new proliferation medium [3].

\subsection{Somatic Embryogenesis Induction}

Putative embryogenic lines were initiated from the radicles and cotyledons of immature zygotic embryos (the immature zygotic embryos were obtained with the procedure explained in Section 3.1), and cultured for three weeks on half-strength MS medium supplemented with Thidiazuron (TDZ) $22.7 \mu \mathrm{M}$, 6-benzylaminopurine (BAP) $4.44 \mu \mathrm{M}$, and 2\% of sucrose. (All the chemicals used in this study were procured from Duchefa Biochemie, Haarlem, Netherlands)

To induce embryogenic calli from the adult material of the studied cultivars, the shoot apex with emerging leaf primordia with or without the first pair of developing leaves in mature wild olive, as suggested by Narvaez et al. [15], have been cut from 21-day-old microshoots, and the protocol adopted by [12] has been followed. Briefly, the above-described explants have been cultured in liquid medium consisting of half-strength MS medium, full strength of MS vitamins, $100 \mathrm{mg} \mathrm{L}^{-1}$ of myo-inositol, $30 \mu \mathrm{M}$ of TDZ, and $0.54 \mu \mathrm{M}$ of NAA, and maintained in a $50 \mathrm{~mL}$ Falcon tube for 4 days in dark conditions at $24 \pm 1{ }^{\circ} \mathrm{C}$, on an orbital shaker at $100 \mathrm{rpm}$. The amount of callus formation has been estimated by an arbitrary scale (0 no callus, $1:<40 \%, 2: 40-80 \%$, and 3: $80-100 \%$ ) for the visual criteria (as recommended by [15]).

\subsection{Expression Phase and Maturation}

After 4 weeks, calli derived from the immature zygotic embryos and from adult material were transferred to a modified expression ECO medium [1] containing 1/4 macroOM; $1 / 4$ micro-MS; $\frac{1}{2}$ NN vitamins [45]; $1 \mathrm{~g} \mathrm{~L}^{-1}$ casein hydrolysate; $0.55 \mathrm{~g} \mathrm{~L}^{-1}$ L-glutamine; and $2 \%$ sucrose; supplemented with $0.4 \mu \mathrm{M}$ of benzylaminopurine (BAP), 0.49 of $\mu \mathrm{M} 6-(\gamma$, $\gamma$-dimethylallylamino) purine (2iP), $0.25 \mu \mathrm{M}$ indole-3-butyric acid (IBA), and cefotaxime (200 $\left.\mathrm{mg} \mathrm{L}^{-1}\right)$. The medium was supplemented with three different ethylene inhibitors: silver nitrate $\left(\mathrm{AgNO}_{3}\right)$, salicylic acid (SA), and cobalt chloride $\left(\mathrm{CoCl}_{2}\right)$ at two concentrations $(20 \mu \mathrm{M}$ and $40 \mu \mathrm{M})$. a survey on somatic embryogenesis has been carried out after four 
weeks in culture. The globular somatic embryos derived from the embryogenic calli of the zygotic embryos from Leccino have been subjected to maturation and conversion, as described by [9]. Briefly, embryos were placed in multiwells with an ECO medium supplemented with $1 \mathrm{~g} \mathrm{~L}^{-1}$ activated charcoal; after 6 weeks the mature embryos were transferred to half-strength OM medium containing mannitol (3.6\%).

\subsection{Culture Conditions}

All culture media were adjusted to $\mathrm{pH} 5.8$ with $1 \mathrm{M} \mathrm{NaOH}$ or $\mathrm{HCl}$, before adding the gelling agent. Both the induction and expression media were solidified with gelrite at $3 \mathrm{~g} \mathrm{~L}^{-1}$, while other maintenance and regeneration media were solidified with plant agar at $5.8 \mathrm{~g} \mathrm{~L}^{-1}$. All media were autoclaved at $121{ }^{\circ} \mathrm{C}$ for $20 \mathrm{~min}$. The induction and expression cultures were incubated in the dark with controlled conditions in a growth chamber at $24 \pm 1{ }^{\circ} \mathrm{C}$, while the proliferation of shoots was routinely carried out under a $16 \mathrm{~h}$ photoperiod, $40 \mu \mathrm{Mol} \mathrm{m} \mathrm{s}^{-2} \mathrm{~s}^{-2}$ PPFD (white LED lights), and at a temperature of $23 \pm 1^{\circ} \mathrm{C}$.

\subsection{Statistical Analysis}

All data was processed by XLSTAT integrated into Microsoft Excel. All the parameters were comprised of three replicates each, and then subjected to analysis of variance (ANOVA) and $t$-test. A Duncan post hoc multiple range test was used for the mean separation and to provide homogeneous groups for the means (at $p \leq 0.05$ ).

\section{Conclusions}

In this study, an efficient and rapid protocol was developed for a more efficient somatic embryogenesis by using ethylene inhibitors, which has paved a path to overcome the double regeneration technique that has been previously adopted for mature tissues of olive cultivars [11]. In addition, this technique is still essential to maintain the morphogenetic callus for many subcultures in several woody species, including olive [6]. Silver nitrate has a stimulatory effect on the somatic embryogenesis of olives, depending on its concentration; $\mathrm{AgNO}_{3}$ at $40 \mu \mathrm{M}$ was the best treatment, producing the highest frequency of somatic embryogenesis in olives, compared to other ethylene inhibitors tested, such as salicylic acid and cobalt chloride. The $\mathrm{AgNO}_{3}$ supposedly inhibits ethylene action by competing with ethylene for the binding sites, and the silver ion can replace the cofactor single copper ion $(\mathrm{Cu})$ present in the ethylene-binding site of the ethylene receptor and lock it to continuously suppress the ethylene response [46]. The positive role of silver nitrate in somatic embryogenesis can contribute to unraveling the recalcitrant nature of the olive species. In future research, it would be advantageous to test the effectiveness of silver nitrate in combination with other ethylene inhibitors for the efficient somatic embryogenesis in olives, particularly cobalt chloride, which also appears as a very promising molecule to be tested in higher concentrations.

Author Contributions: Conceptualization, methodology, and investigation, M.A.B., C.S. and E.R., resources, data curation, and funding acquisition, A.S. and S.Z.; writing-original draft preparation, M.A.B. and C.S.; writing-review and editing, C.S., E.R. and V.C.; supervision and project administration, C.S., S.Z. and V.C. All authors have read and agreed to the published version of the manuscript.

Funding: The research was partially supported by MIPAAF-BIOTECH-GENOLICS-Optimization of in vitro olive regeneration protocols and finding of allele variants for modern biotechnologies, and by the funding of MIUR (Ministry for Education, University and Research), Law 232/2016, "Department of Excellence".

Institutional Review Board Statement: Not applicable.

Informed Consent Statement: Not applicable.

Conflicts of Interest: The authors declare no conflict of interest. 


\section{References}

1. Rugini, E.; Silvestri, C. Somatic Embryogenesis in Olive (Olea europaea L. subsp. europaea var. sativa and var. sylvestris). In In Vitro Embryogenesis in Higher Plants; Germana, M.A., Lambardi, M., Eds.; Humana Press: New York, NY, USA, 2016; pp. 341-349.

2. Rugini, E.; Cristofori, V.; Silvestri, C. Genetic improvement of olive (Olea europaea L.) by conventional and in vitro biotechnology methods. Biotechnol. Adv. 2016, 34, 687-696. [CrossRef]

3. Rugini, E. In vitro propagation of some olive cultivars with different root-ability and medium development using analytical data from developing shoots and embryos. Sci. Hortic. 1984, 24, 123-134. [CrossRef]

4. Regni, L.; Micheli, M.; Del Pino, A.M.; Palmerini, C.A.; D’Amato, R.; Facchin, S.L.; Famiani, F.; Peruzzi, A.; Mairech, H.; Proietti, P. The first evidence of the beneficial effects of se-supplementation on in vitro cultivated olive tree explants. Plants 2021, 10, 1630. [CrossRef]

5. Leva, A.R.; Muleo, R.; Petruccelli, R. Long-term somatic embryogenesis from immature olive cotyledons. J. Hortic. Sci. Biotechnol. 1995, 70, 417-421. [CrossRef]

6. Rugini, E. Somatic embryogenesis and plant regeneration in olive (Olea europaea L.). Plant Cell Tissue Org. Cult. 1988, 14, 207-214. [CrossRef]

7. Orinos, P.; Mitrakos, K. Rhizogenesis and somatic embryogenesis in calli from wild olive (Olea europaea var sylvestris (Miller) Lehr) mature zygotic embryos. Plant Cell Tissue Organ Cult. 1991, 27, 183-187. [CrossRef]

8. Mitrakos, K.; Alexaki, A.; Papadimitriou, P. Dependence of olive morphogenesis on callus origin and age. J. Plant Physiol. 1992, 139, 269-273. [CrossRef]

9. Cerezo, S.; Mercado, J.A.; Pliego-Alfaro, F. An efficient regeneration system via somatic embryogenesis in olive. Plant Cell Tissue Org. Cult. 2011, 106, 337-344. [CrossRef]

10. Shibli, R.A.; Shatnawi, M.; Abu, E.; Al-Juboory, K.H. Somatic embryogenesis and plant recovery from callus of 'Nabali' Olive (Olea europaea L.). Sci. Hortic. 2001, 88, 243-256. [CrossRef]

11. Rugini, E.; Caricato, G. Somatic embryogenesis and plant recovery from mature tissues of olive cultivars (Olea europaea L.) 'Canino' and 'Moraiolo'. Plant Cell Rep. 1995, 14, 257-260. [CrossRef]

12. Mazri, M.A.; Belkoura, I.; Pliego-Alfaro, F.; Belkoura, M. Somatic embryogenesis from leaf and petiole explants of the Moroccan olive cultivar dahbia. Sci. Hortic. 2013, 159, 88-95. [CrossRef]

13. Toufik, I.; Guenoun, F.; Belkoura, I. Embryogenesis expression from somatic explants of olive (Olea europaea L.) cv Picual. Moroccan J. Biol. 2014, 11, 17-25.

14. Capelo, A.M.; Silva, S.; Brito, G.; Santos, C. Somatic embryogenesis induction in leaves and petioles of a mature wild olive. Plant Cell Tissue Org. Cult. 2010, 103, 237-242. [CrossRef]

15. Narváez, I.; Martín, C.; Jiménez-Díaz, R.M.; Mercado, J.A.; Pliego-Alfaro, F. Plant regeneration via somatic embryogenesis in mature wild olive genotypes resistant to the defoliating pathotype of verticillium dahliae. Front. Plant Sci. 2019, 10, 1471. [CrossRef]

16. Sánchez-Romero, C. Somatic embryogenesis in olea spp. Plant Cell Tissue Org Cult. 2019, 138, 403-426. [CrossRef]

17. Kumar, V.; Ramakrishna, A.; Ravishankar, G.A. Influence of different ethylene inhibitors on somatic embryogenesis and secondary embryogenesis from Coffea canephora P ex Fr. In Vitro Cellular Developmental Biology-Plant 2007, 43, 602-607. [CrossRef]

18. Schaller, G.E.; Binder, B.M. Inhibitors of ethylene biosynthesis and signaling. In Ethylene Signaling: Methods and Protocols; Binder, B.M., Schaller, G.E., Eds.; Humana Press: New York, NY, USA, 2017; pp. 223-235.

19. Sgamma, T.; Thomas, B.; Muleo, R. Ethylene inhibitor silver nitrate enhances regeneration and genetic transformation of prunus avium (L.) cv stella. Plant Cell Tissue Org. Cult. 2015, 120, 79-88. [CrossRef]

20. Fuentes, S.R.; Calheiros, M.B.; Manetti-Filho, J.; Vieira, L.G. The effects of silver nitrate and different carbohydrate sources on somatic embryogenesis in Coffea canephora. Plant Cell Tissue Org. Cult. 2000, 60, 5-13. [CrossRef]

21. Huang, Y.F.; Chen, C.T.; Kao, C.H. Salicylic acid inhibits the biosynthesis of ethylene in detached rice leaves. Plant Growth Reg. 1993, 12, 79-82. [CrossRef]

22. Roustan, J.P.; Latche, A.; Fallot, J. Role of ethylene on induction and expression of carrot somatic embryogenesis: Relationship with polyamine metabolism. Plant Sci. 1994, 103, 223-229. [CrossRef]

23. Bais, H.P.; Sudha, G.S.; Ravishankar, G.A. Influence of putrescine $\mathrm{AgNO}_{3}$ and polyamine inhibitors on the morphogenetic response in untransformed and transformed tissues of Cichorium intybus and their regenerants. Plant Cell Rep. 2001, 20, 547-555. [CrossRef]

24. Kumar, V.; Parvatam, G.; Ravishankar, G.A. $\mathrm{AgNO}_{3}$ : A potential regulator of ethylene activity and plant growth modulator. Elect J. Biotechnol. 2009, 12, 8-9. [CrossRef]

25. Yu, Y.B.; Yang, S.F. Auxin-induced ethylene production and its inhibition by aminoethyoxyvinylglycine and cobalt ion. Plant Physiol. 1979, 64, 1074-1077. [CrossRef] [PubMed]

26. Leslie, C.A.; Romani, R.J. Inhibition of ethylene biosynthesis by salicylic acid. Plant Physiol. 1988, 88, 833-837. [CrossRef] [PubMed]

27. Neves, M.; Correia, S.; Cavaleiro, C.; Canhoto, J. Modulation of Organogenesis and Somatic Embryogenesis by Ethylene: An Overview. Plants 2021, 10, 1208. [CrossRef] [PubMed]

28. Ikeuchi, M.; Ogawa, Y.; Iwase, A.; Sugimoto, K. Plant regeneration: Cellular origins and molecular mechanisms. Development 2016, 143, 1442-1451. [CrossRef] 
29. Bhatia, S.; Bera, T. Somatic embryogenesis and organogenesis. In Modern Applications of Plant Biotechnology in Pharmaceutical Sciences; Bhatia, S., Sharma, K., Dahiya, R., Bera, T., Eds.; Academic Press: Cambridge, MA, USA, 2015; pp. $209-230$.

30. Tamimi, S.M. Effects of ethylene inhibitors, silver nitrate $\left(\mathrm{AgNO}_{3}\right)$ cobalt chloride $\left(\mathrm{CoCl}_{2}\right)$ and aminooxyacetic acid (AOA), on in vitro shoot induction and rooting of Banana (Musa acuminata L.). Afr. J. Biotechnol. 2015, 14, 2510-2516.

31. Giridhar, P.; Indu, E.P.; Vinod, K.; Chandrashekar, A.; Ravishankar, G.A. Direct somatic embryogenesis from Coffea arabica L and Coffea canephora P ex Fr. under the influence of ethylene action inhibitor-silver nitrate. Acta Physiol. Plant 2004, 26, 299-305. [CrossRef]

32. Qin, Y.; Zhang, S.; Zhang, L.X.; Zhu, D.; Asghar, S. Response of strawberry cv. Toyonokain vitro to silver nitrate (AgNO $)_{3}$. Hortscience 2005, 40, 747-751. [CrossRef]

33. Gong, Y.; Gao, F.; Tang, K. In vitro high frequency direct root and shoot regeneration in sweet potato using the ethylene inhibitor silver nitrate. S. Afr. J. Bot. 2005, 71, 110-113. [CrossRef]

34. Abdellatef, E.; Ahmed, M.; Daffall, H.; Khalafalla, M. Enhancement of adventitious shoot regeneration in sesame (Sesamum indicum L.) cultivar Promo ky using ethylene inhibitors. J. Phytol. 2010, 2, 61-67.

35. Osman, M.G.; Khalafalla, M. Promotion of in vitro shoot formation from shoot tip of tomato (Lycopersicon esculentum mill. cv. omdurman) by ethylene inhibitors. Int. J. Curr. Res. 2010, 4, 82-86.

36. Dikash, S.; Devala, D.; Punyarani, K.; Henary, S.; Brojendro, S.S.; Brajakishor, S.; Sunitibala, H.D. Silver nitrate and different culture vessels influence high frequency microrhizome induction in vitro and enhancement growth of turmeric plantlet during ex vitro acclimatization. Not. Sci. Biol. 2012, 4, 67-78.

37. Pua, E.C.; Chi, G.L. De novo shoot morphogenesis and plant growth of mustard (Brassica juncea) in vitro in relation to ethylene. Physiol. Plant 1993, 88, 467-474. [CrossRef]

38. Abeles, F.B.; Morgan, P.W.; Saltiveit, M.E. Ethylene in Plant Biology, 2nd ed.; Academic Press: San Diego, CA, USA, 1992.

39. Palei, S.; Das, A.K.; Rout, G.R. In vitro studies of strawberry-An important fruit crop: A review. J. Plant Sci. Res. 2015, 31, 115-131.

40. Saiprasad, G.V.S.; Raghuveer, P. Influence of ethylene inhibitors and ethrel on production of protocorm like bodies in orchiddendrobium 'sonia'. J. Horticul. Sci. 2007, 2, 13-18.

41. Sankhla, D.; Sankhla, N.; Davis, T.D. Promotion of in vitro shoot formation from excised roots of silk tree by an oxime ether derivative and other ethylene inhibitors. Plant Cell Rep. 1995, 15, 143-146. [CrossRef] [PubMed]

42. Kong, D.; Shen, H.; Li, N. Influence of $\mathrm{AgNO}_{3}$ on somatic embryo induction and development in Manchurian ash (Fraxinus mandshurica Rupr.). Afr. J. Biotechnol. 2011, 11, 120-125.

43. Al-Khayri, J.M.; Al-Bahrany, A.M. Genotype-dependent in vitro response of date palm (Phoenix dactylifera L.) cultivars to silver nitrate. Sci. Hortic. 2004, 99, 153-162. [CrossRef]

44. Kumar, S.; Sarkar, A.K.; Kuhikannan, C. Regeneration of plants from leaflet explants of tissue culture raised Safed Siris (Albizia procera). Plant Cell Tissue Organ Cult. 1998, 54, 137-143. [CrossRef]

45. Nitsch, J.P.; Nitsch, C. Haploid plants from pollen grains. Science 1969, 163, 85-87. [CrossRef]

46. Zhao, X.C.; Qu, X.; Mathews, D.E.; Schaller, G.E. Effect of ethylene pathway mutations upon expression of the ethylene receptor ETR1 from Arabidopsis. Plant Physiol. 2002, 130, 1983-1991. [CrossRef] 